Imagining the Arabs 



\section{Imagining the Arabs}

Arab Identity and the Rise of Islam

\section{Peter Webh}

EDINBURGH

University Press 
Edinburgh University Press is one of the leading university presses in the UK. We publish academic books and journals in our selected subject areas across the humanities and social sciences, combining cuttingedge scholarship with high editorial and production values to produce academic works of lasting importance. For more information visit our website: www.edinburghuniversitypress.com

(C) Peter Webb, 2016

Edinburgh University Press Ltd

The Tun - Holyrood Road

12 (2f) Jackson's Entry

Edinburgh EH8 8PJ

Typeset in 11/15 Adobe Garamond by Servis Filmsetting Ltd, Stockport, Cheshire, and printed and bound in Great Britain by CPI Group (UK) Ltd, Croydon CR0 4YY

A CIP record for this book is available from the British Library

ISBN 9781474408264 (hardback)

ISBN 9781474408271 (webready PDF)

ISBN 9781474408288 (epub)

The right of Peter Webb to be identified as author of this work has been asserted in accordance with the Copyright, Designs and Patents Act 1988 and the Copyright and Related Rights Regulations 2003 (SI No. 2498). 